\title{
OPTIMALISASI PENGELOLAAN DAN PEMBERDAYAAN PULAU-PULAU TERLUAR DALAM RANGKA MEMPERTAHANKAN KEUTUHAN NEGARA KESATUAN REPUBLIK INDONESIA
}

\author{
Ayub Torry Satriyo Kusumo \\ Fakultas Hukum Universitas Sebelas Maret, Surakarta \\ E-mail: ayub_satriyo@yahoo.com
}

\begin{abstract}
Indonesia is an archipelago with the most numerous islands with their resources, including the ones owned in its outmost islands. The outmost islands are rich in various resources but have not been managed yet. Those islands are also the first guard which acts as safeguard for the unity of Indonesia. Unfortunately, the government has not paid a comprehensive concern to those islands and it results in successful claim of Sipadan and Ligitan Islands by the neighbor country based on their effective occupation toward those islands. It will endanger the entirety of Indonesia and cause a great lost economically. Therefore, by the way of good protection and management of the outmost islands, the unity of Indonesia will be defended and the welfare of Indonesian will be enhanced.
\end{abstract}

Keywords: the outmost islands, empowerment, state sovereignty.

\begin{abstract}
Abstrak
Negara Kesatuan Republik Indonesia merupakan negara kepulauan yang dengan jumlah pulau terbesar di dunia dan memiliki kekayaan yang berlimpah, tak terkecuali yang terkandung dalam pulau-pulau terluarnya. Pulau-pulau terluar merupakan sumber kekayaan yang belum tergarap sekaligus garda depan ketahanan dan keamanan negara. Meskipun demikian, ternyata pemerintah Indonesia belum sepenuhnya memberdayakan dan mengelola pulau-pulau terluar secara optimal. Akibatnya, pemerintah Indonesia harus merelakan Pulau Sipadan dan Ligitan karena dinilai tidak melakukan pengelolaan yang efektif. Hal ini cukup membahayakan keutuhan Negara Kesatuan Republik Indonesia selain merugikan negara dalam bidang ekonomi. Melalui usaha-usaha pengelolaan dan pemberdayaan pulau-pulau terluar, kesejahteraan rakyat dan keutuhan negara Republik Indonesia dapat dipertahankan.
\end{abstract}

Kata kunci : Pemberdayaan, Pulau terluar, kedaulatan negara.

\section{Pendahuluan}

Indonesia merupakan negara dengan jumlah pulau terbesar di dunia. Dalam UndangUndang Dasar 1945 ditetapkan Indonesia sebagai sebuah negara kepulauan yaitu negara yang memiliki banyak pulau yaitu sejumlah 17.480 pulau dengan panjang garis pantai mencapai $95.181 \mathrm{~km}$. Sembilan puluh dua pulau kecil di antaranya adalah pulau-pulau kecil terluar. ${ }^{1}$

\footnotetext{
Syamsul Ma'arif, 2009, Makalah Pengelolaan Pulau Terluar dalam Manajemen Pulau Terluar, Fakultas Geografi UGM, 23 J anuari 2009.
}

Pulau-Pulau kecil menyediakan sumber daya alam yang produktif untuk dapat dikembangkan misalnya terumbu karang, padang lamun (sea grass), hutan mangrove, perikanan, dan kawasan konservasi serta menjadi faktor penting dalam meggerakkan pariwisata bahari. ${ }^{2}$ Akan tetapi melihat realitas yang ada saat ini, kekayaaan alam maupun pulau-pulau kecil rentan kerusakan, baik itu dari alam maupun akibat tindakan manusia seperti pencemaran,

\footnotetext{
Dinas Kelautan dan Perikanan, 2010, diakses pada website http:// www.dkp.go.id/ content. php?c=4286 pada tanggal 5 Maret 2010.
} 
perusakan ekosistem, dan penangkapan ikan secara berlebihan (overfishing).

United Nations Confention on the Law Of the Sea (UNCLOS) 1982 mengatur bahwa negara kepulauan adalah negara yang terdiri atas satu atau lebih gugusan pulau, di mana di antaranya terdapat pulau-pulau lain yang merupakan satu kesatuan politik atau secara historis merupakan satu ikatan. ${ }^{3}$ Adapun yang dimaksud dengan pulau menurut UNCLOS adalah daratan yang dibentuk alami dan dikelilingi oleh air dan selalu berada di atas muka air pasang tinggi.

UNCLOS mengatur tentang rezim-rezim hukum laut, termasuk hukum negara kepulauan (yang mempunyai arti dan peranan penting untuk memantapkan kedudukan Indonesia dalam rangka implementasi wawasan nusantara sesuai amanat MPR RI) secara menyeluruh. ${ }^{4}$ Sedangkan dalam Undang-Undang RI nomor 6 tahun 1996, luas Kepulauan Indonesia dan laut teritorialnya adalah 3,1 juta kilometer persegi (diukur 12 mil dari garis pangkal pada surut terendah), sedangkan luas Zona Ekonomi Ekslusif (ZEE) yang dimiliki adalah 2,7 juta kilometer persegi yang menyangkut hak eksplorasi, eksploitasi dan pengelolaan sumberdaya hayati dan non hayati. Dengan konsep negara kepulauan ini, Indonesia memiliki hak secara penuh atas perairan yang di sisi pulau-pulau tersebut. Bukan hanya itu, Indonesia juga berhak atas ruang angkasa serta apa-apa yang berada di dasar laut. Indonesia memiliki aset kekayaan alam yang luar biasa melimpah, kekayaan tersebut secara cuma-cuma diberikan oleh Tuhan kepada Indonesia baik hayati maupun non-hayati. Kekayaan tersebut memungkinkan adanya pertumbuhan ekonomi yang pesat khususnya yang bersumber dari kekayaan tersebut, jika ditangani dengan optimal baik oleh pemerintah pusat maupun pemerintah daerah. Bahkan, Indonesia dikatakan sebagai

\footnotetext{
Anonim, Permasalahan Kelautan Yang Muncul Dalam Negara Kepulauan Indonesia, diakses pada website http:/ / www. sumbawanews. com/ berita/ opini/ permasala han-kelautan-yang-muncul-dalam-negara-kepulauanindonesia/ pdf.html tanggal 5 Maret 2010.

4 Suryo Sakti Hadiwijoyo, 2009, Batas Wilayah Negara Indonesia Dimensi, Permasalahan, dan strategi Penanganan Sebuah Tinjauan Empiris dan Yuridis, Yogyakarta : PT Gava Media, hlm. 113.
}

negara yang gemah ripah loh jinawi, pepatah yang menggambarkan bagaimana melimpahruahnya kekayaan alam yang ada di Indonesia. Mulai dari kekayaan laut dengan bermacammacam ikan di dalamnya, hingga hutan yang mampu menyumbangkan oksigen ke seluruh penjuru dunia, sehingga Indonesia juga disebut sebagai paru-paru dunia. Akan tetapi melihat kenyataan yang ada saat ini, kekayaaan-kekayaan yang dimilki oleh Indonesia belum dimanfaatkan secara optimal oleh pemerintah, begitu juga dengan penanganan pulau-pulau di Indonesia yang belum mencapai kata "optimal" seperti yang diharapkan. Masih banyak pulaupulau yang belum terurus, bahkan masih ada yang belum disebut atau diberi nama. Terdapat 92 pulau terluar yang tersebar di wilayah NKRI dengan luas masing-masing pulau rata-rata 0,02 hingga 200 kilometer persegi. Hanya 50\% dari pulau terluar tersebut yang berpenghuni. Enam puluh tuj uh dari 92 pulau terluar itu berbatasan dengan negara tetangga yaitu India, Thailand, Malaysia, Singapura, Vietnam, Philipina, Palau Papua New Guinea, Australia, dan Timor Leste. $^{5}$

Adanya perbatasan langsung antara pulau-pulau terluar Indonesia dengan negaranegara tetangga ini memiliki potensi yang besar akan timbulnya persengketaan antara kedua belah pihak. Adapun salah satu permasalahannya adalah status pulau-pulau terluar. Permasalahan status Pulau terluar dapat diantisipasi dengan lengkah-langkah strategis dan operasional dalam mempertahankan eksistensi pulau terluar dengan penekanan implementasi Pasal 46 tentang archipelagic state dan Pasal 47 tentang archipelagic base line ${ }^{6}$. Kasus Sipadan dan Ligitan sudah menjadi tamparan keras bagi kita bahwa kurangnya penanganan terhadap pulau-pulau terluar mengakibatkan lepasnya pulau-pulau tersebut dari kepemilikan pemerintah Indonesia. Bahkan saat ini ada 12 pulau yang memerlukan perhatian khusus oleh

\footnotetext{
5 Bambang Susanto, Kajian Yuridis Permasalahan Batas Maritim Wilayah Laut Republik Indonesia (Suatu Pandangan TNI AL Bagi Pengamanan Batas wilayah Laut RI), Indonesian Journal of International Law, Special Edition December 2004, hlm. 44.

$6 \mathrm{lbid}, \mathrm{hlm} .46$.
} 
pemerintah, yaitu Pulau Rondo, Pulau Sekatung, Pulau Nipa, Pulau Berhala, Pulau Miangas, Pulau Marapit, Pulau Bross, Pulau Fanildo, Pulau Marore, Pulau Batik, dan Pulau Dana. ${ }^{7}$ Pulau-pulau itu terhampar dari Aceh hingga Papua. Kita tidak akan pernah membiarkan pulau-pulau itu akan mengalami nasib yang sama dengan Sipadan dan Ligitan.

Pemerintah pusat maupun pemerintah daerah dianggap kurang serius menangani masalah ini, sehingga menyebabkan terkikisnya rasa nasionalisme penduduk yang menghuni pulau-pulau terluar. Mereka sudah tidak merasa bahwa dirinya adalah warga negara Indonesia. Mereka lebih memilih berbelanja kebutuhan sehari-hari mereka di negara tetangga yang kawasannya sangat dekat dengan tempat tinggalnya. Pada umumnya penduduk tersebut memiliki kartu pass ${ }^{8}$, sehingga dapat keluarmasuk ke negara tetangga. Adanya kegiatan perekonomian dengan intensitas cukup tinggi antara negara tetangga dengan penduduk pulau terluar, dapat pula menjadi dasar klaim atas pulau tersebut oleh negara tetangga. ${ }^{9} \mathrm{Ke}-$ budayaan penduduk di pulau-pulau terluar yang berbatasan langsung dengan negara tetangga lebih kental dengan pengaruh budaya negara tetangga daripada budaya Indonesia sendiri. Hal-hal seperti inilah yang sangat membahayakan ketahanan dan integritas bangsa Indonesia.

Tidak sedikit pula kasus penangkapan nelayan-nelayan "nakal" dari luar negeri yang secara sengaja masuk ke kawasan perairan Indonesia untuk mengambil ikan maupun kekayaan laut lainnya. Kapal-kapal patroli negara-negara luar mulai masuk ke perairan Indonesia yang seharusnya mereka tidak berhak atas perairan tersebut. Masuknya penduduk negara tetangga maupun kapal-kapal patroli

\footnotetext{
7 Departemen Luar Negeri RI, diakses pada website http:// www. deplu.go.id/ Pages/ News. aspx?IDP=38\&I=id pada tanggal 7 Maret 2010.

8 Kartu Pass secara sederhana merupakan kartu yang digunakan orang di perbatasan untuk melintas ke negara lain (misal keperluan belanja), yang nantinya akan dilegalisasi oleh petugas perbatasan.

9 Brian Taylor Sumner, Territorial Disputes at The International Court of J ustice, Duke Law J ournal, 2004, 53, hlm. 1784
}

mereka akan membahayakan kepemilikan pulau-pulau terluar itu oleh negara Republik Indonesia. Hal ini akan diperburuk oleh kurangnya perhatian dan pendayagunaan pulau terluar beserta segala sumberdayanya oleh Indonesia, karena negara tetangga dapat dengan mudah melakukan klaim atas kepemilikan pulau-pulau tersebut dengan alasan kepengurusan dan penggunaan sumber daya pulau tersebut secara efektif. Di saat itu terjadi, kedaulatan negara Indonesia dapat terancam.

Pada dasarnya, pemerintah telah mengatur melalui Perpres No. 78 Tahun 2005 dan UU No. 27 Tahun 2007 tentang Pengelolaan Pulau Terluar. Pemerintah telah mempersiapkan 22 departemen yang memiliki 35 program untuk membangun di wilayah perbatasan, sehingga dengan pembentukan organisasi yang tepat dan efektif seluruh program dapat dikoordinasikan. ${ }^{10}$ Namun demikian, akibat kurangnya pengawasan dari pemerintah pusat maupun pemerintah daerah setempat, program-program itu belum sepenuhnya direalisasikan, bahkan dapat dikatakan masih sangat kurang realisasinya.

Upaya pengembangan dan pemberdayaan pulau-pulau kecil harus dilakukan secara lintas bidang dan lintas wilayah yang bertujuan untuk meningkatkan manfaat dan karakteristik wilayah Indonesia untuk kemakmuran rakyat dan juga untuk mengurangi kesenjangan antar wilayah. Untuk mencapai hal tersebut, dibutuhkan suatu penanganan secara holistik dan terintegrasi dalam suatu sistem sehingga pendayagunaan pulau-pulau kecil dapat dilakukan secara efektif.

Tulisan ini bertujuan untuk memberikan data tentang kondisi riil tentang pulau-pulau kecil terluar beserta potensi yang dimiliki, serta memberikan gagasan atupun ide penanganan dan pemanfaatan pulau-pulau kecil dalam peningkatan ekonomi masyarakat daerah. Diharapkan melalui tulisan ini dapat memberikan manfaat berupa gagasan untuk pembangunan dan pemberdayaan pulau-pulau terluar dengan pendekatan kesejahteraan dan keamanan bagi

\footnotetext{
${ }^{10}$ Kantor Berita Antara, diakses pada website http:// www. antara. co.id $/$ view $/ ? i=1228482066 \& c=N A S \& s=$ pada tanggal 5 Februari 2010.
} 
masyarakatnya serta lingkungannya secara serasi. Di samping itu, diharapkan tulisan ini dapat memberikan sumbangan ide dalam rangka peningkatan peran pemerintah daerah dalam usaha penanganan pulau-pulau kecil dan perlindungan sumberdaya alam di dalamnya.

\section{Pembahasan}

\section{Konsep Wilayah Negara Menurut Hukum Inter- nasional}

Pasal 1 Konvensi Motevideo 1933 mengenai hak-hak dan kewajiban-kewajiban negara, mengatur bahwa salah satu unsur negara adalah wilayah ${ }^{11}$. Wilayah adalah suatu ruang di mana orang yang menjadi warga negara atau penduduk negara yang bersangkutan hidup serta menjalankan segala aktivitasnya. Wilayah merupakan unsur mutlak yang harus dipenuhi untuk menyatakan entitas sebagai negara karena dengan wilayah, suatu negara dapat menggunakan kedaulatannya dalam hal penerapan aturan maupun sanksi.

Konsep wilayah negara memberikan prinsip non-intervensi dalam persoalan yang mencakup yurisdiksi domestik dan prinsip untuk menghormati integritas wilayah negara lain. ${ }^{12}$ Dalam sejarah kehidupan umat manusia maupun negara-negara, seringkali terjadi konflikkonflik yang bersumberkan pada masalah wilayah. Konflik ini bisa disebabkan oleh karena keinginan untuk melakukan ekspansi wilayah maupun ketidakjelasan batas-batas wilayah antarnegara. Tetapi dengan semakin meningkatnya penghormatan atas kedaulatan teritorial negara-negara, terutama setelah Perang Dunia II (PD II), usaha untuk melakukan ekspansi wilayah menjadi berkurang bahkan boleh dikatakan sudah tidak ada.

Namun demikian, konflik-konflik antar negara akibat ketidakjelasan batas-batas wilayah di pelbagai bagian dunia ini masih tetap ada dan sesekali muncul sebagai suatu konflik bersenjata. ${ }^{13}$ Sebagai contoh, konflik antara In-

\footnotetext{
11 J awahir Thontowi, 2006, Hukum Internasional Kontemporer, Bandung: Refika Aditama, hlm. 177.

12 Malcolm N Shaw, 1997, International Law, Cambridge: Cambridge University Press, hlm. 330.

${ }^{13}$ I Wayan Parthiana, 2003, Pengantar Hukum Internasional, Bandung: Mandar Maju, hlm. 146.
}

dia dan Republik Rakyat Cina pada tahun 1965 mengenai garis batas wilayah kedua negara di daerah pegunungan Himalaya. Demikian pula konflik antara India dan Pakistan mengenai masalah garis batas wilayah di daerah Kashmir. Beberapa contoh lain yang dapat ditambahkan antara lain persengketaan Denmark dengan Norwegia mengenai status dari wilayah Greenlandia Timur (Eastern Greenland) ${ }^{14}$ dan sengketa antara Indonesia dengan Malaysia terkait Pulau Sipadan dan Pulau Ligitan di kawasan timur Kalimantan. ${ }^{15}$ Meskipun wilayah merupakan salah satu unsur yang penting bagi suatu negara, dalam sejarah kehidupan negara-negara pernah terjadi di mana suatu negara yang pada permulaan berdirinya belum memiliki batas-batas wilayah yang jelas ${ }^{16}$ namun sudah diakui sebagai sebuah negara berdaulat.

\section{Bagian-Bagian Wilayah Negara}

Wilayah negara terdiri atas daratan termasuk tanah di bawahnya, perairan dan tanah di bawahnya, serta ruang udara. Wilayah daratan dan ruang udara dimiliki oleh setiap negara sedangkan wilayah perairan, khususnya wilayah laut, hanya dimiliki oleh negara pantai atau negara yang di hadapan pantainya terdapat laut.

Wilayah daratan adalah bagian dari daratan yang merupakan tempat pemukiman atau kediaman dari warga negara atau penduduk negara yang bersangkutan. Antara wilayah daratan negara yang satu dengan yang lainnya harus tegas batas-batas wilayahnya dengan ditetapkannya perjanjian-perj anj ian garis batas wilayah antara negara-negara yang berbatasan itu.

\footnotetext{
${ }^{14}$ Permanent Court of J ustice tahun 1933 telah memutus sengketa antara Denmark melawan Norwegia dengan kemenangan pihak Denmark.

${ }^{15}$ Mahkamah Internasional memenangkan Malaysia dengan alasan effective occupation oleh Malaysia terhadap Sipadan dan Ligitan.

16 Israel pada waktu memproklamasikan kemerdekaannya pada tahun 1948, batas-batas wilayahnya belum jelas. Demikian pula halnya dengan berdirinya negara Palestina Merdeka yang diproklamasikan kemerdekaannya pada 15 Nopember tahun 1988, batas-batas wilayahnya sama sekali belum jelas bahkan pemerintahnya pun masih berada di negara lain yaitu Tunisia, sebagai pemerintah dalam pengasingan.
} 
Ruang lingkup wilayah daratan tidak saja permukaan tanah daratan, tetapi juga tanah di bawah daratan tersebut. Mengenai batas kedalaman dari tanah di bawah daratan yang merupakan wilayah negara, sampai kini tidak ada pengaturannya. Oleh karena itu dapat dikatakan bahwa kedaulatan negara atas wilayah tanah di bawah daratan tersebut, adalah sampai pada kedalaman yang tidak terbatas. Negara itu memiliki kedaulatan yang permanen atas sumber-sumber daya alam yang terkandung di dalamnya.

Garis batas wilayah suatu negara ada pula yang terletak pada sungai yang mengalir di perbatasan wilayah kedua negara. Dalam hal ini, maka garis batas wilayahnya adalah pada tengah-tengah dari aliran sungai tersebut. Atau bisa juga dengan menetapkan garis batas wilayah negara-negara itu pada bagian-bagian terdalam dari sungai itu, yang disebut dengan thalweg ${ }^{17}$.

Wilayah perairan atau disebut juga perairan teritorial adalah bagian perairan yang merupakan wilayah suatu negara ${ }^{18}$. Tidak semua negara di dunia ini memiliki wilayah perairan. Negara-negara yang seluruh wilayah daratannya dikelilingi oleh wilayah daratan negara-negara lain disebut negara tak berpantai atau negara buntu (land lock states). Negara-negara buntu ini tidak memiliki wilayah perairan. Misalnya negara Afganistan, Laos, Nepal dan Bhutan di Asia; negara Afrika Tengah, Uganda, Niger dan Chad di Afrika; negara Swiss, Austria, Hongaria dan Luxemburg di Eropa; serta negara Paraguay di Amerika Latin.

Wilayah perairan ini dibagi lagi menjadi beberapa macam yaitu pertama Laut territorial, Laut Teritorial adalah laut yang terletak pada sisi luar dari garis pangkal (base line) dan di sebelah luarnya dibatasi garis batas luar (outer limit) tidak melebihi 12 mil laut. ${ }^{19} \mathrm{Di}$ daIam Laut Teritorial, negara mempunyai ke-

\footnotetext{
17 I Wayan Parthiana, op.cit., hlm. 149.

18 Ini berarti bahwa, di samping perairan yang tunduk pada kedaulatan negara karena merupakan bagian wilayahnya, ada pula bagian perairan yang berada di luar wilayahnya atau tidak tunduk pada kedaulatan negara. Perairan seperti ini misalnya adalah laut lepas (high seas).

${ }_{19}$ Adapun yang dimaksud dengan garis pangkal bukan merupakan garis dalam pengertian nyata.
}

daulatan penuh atas yurisdiksinya termasuk hak lintas damai bagi kapal asing. ${ }^{20}$

Kedua, Perairan pedalaman yang merupakan perairan yang berada pada sisi darat (dalam) garis pangkal. Di perairan pedalaman ini negara memiliki kedaulatan penuh atasnya. Sehingga tidak ada kapal asing yang diperbolehkan masuk ke dalam wilayah ini kecuali dalam keadaan yang sangat genting atau memaksa ${ }^{21}$. Namun kalau perairan pedalaman ini terbentuk karena adanya penarikan garis pangkal lurus, maka hak lintas damai di perairan tersebut dapat dinikmati oleh negaranegara lain. Perairan pedalaman ini meliputi (1) Laut pedalaman, dan (2) Perairan darat.

Ketiga, Selat, selat di sini adalah selat yang dipergunakan untuk pelayaran internasional (straits used for internasional navigation). ${ }^{22}$ Ada dua kategori dalam selat ini. Pertama, adalah selat-selat yang dipergunakan bagi pelayaran internasional yang menghubungkan suatu laut lepas atau ZEE dengan laut lepas atau ZEE lainnya. Hal tersebut berlaku hak lintas transit kapal asing. ${ }^{23}$ Kedua, adalah selatselat yang menghubungkan laut lepas atau ZEE dengan perairan yang termasuk dalam jurisdiksi nasional (laut teritorial) suatu negara asing.

Keempat, jalur tambahan. Zona tambahan merupakan zona dalam laut yang terletak pada sisi luar garis pangkal dan berada di luar laut territorial diukur sejauh 24 mil laut dari garis pangkal. Dalam zona tambahan negara mempunyai kekuasaan terbatas untuk mencegah pelanggaran terhadap peraturanperaturan bea cukai, fiskal, imigrasi, dan kesehatan.

\footnotetext{
${ }^{20}$ Menurut Konvensi Hukum Laut 1982, Hak lintas damai merupakan hak untuk melintas secepat-cepatnya tanpa berhenti dan bersifat damai tidak menggangu kemanan dan ketertiban negara pantai.

${ }^{21}$ J ika kapal asing melakukan hak lintas damai, maka kapal tersebut menjadi subyek hukum nasional negara pemilik perairan pedalaman tersebut.

22 Diatur dalam Pasal 34 dan Pasal 35 Konvensi Hukum Laut 1982. Negara-negara yang berada di tepi selat juga mempunyai yurisdiksi penuh.

${ }^{23}$ Hak lintas transit adalah hak untuk melewati suatu selat yang dipergunakan untuk pelayaran internasional secara terus menerus, langsung dan secepat mungkin antara suatu bagian laut lepas atau ZEE dan bagian laut lepas atau ZEE.
} 
Kelima, landas kontinen. Konvensi mendefinisikan landas kontinen sebagai dasar laut dan tanah di bawahnya dari area di bawah permukaan laut yang terletak di luar laut teritorial sepanjang kelanjutan alamiah wilayah daratannya hingga pinggiran luar tepi kontinen atau hingga jarak 200 mil laut dari garis pangkal dari mana lebar laut tepi kontinen tidak mencapai jarak tersebut.

Keenam, Zone Ekonomi Ekslusif (ZEE). ZEE adalah zona selebar tidak lebih dari 200 mil laut dari garis pangkal. Yurisdiksi yang dimiliki negara pantai atas ZEE adalah Pembuatan dan pemakaian pulau buatan, instalasi dan bangunan, riset ilmiah kelautan, serta perlindungan dan pelestarian lingkungan laut. ${ }^{24}$

Ketujuh, laut lepas. Laut lepas merupakan res communis, yaitu laut yang terbuka dan bebas bagi semua negara. ${ }^{25}$ Berkaitan dengan kedaulatan negara, suatu negara mempunyai suatu hak pengejaran seketika (the right of hot pursuit). ${ }^{26}$ Pengejaran seketika adalah hak setiap negara pantai untuk melaksanakan suatu pengejaran seketika terhadap kapal asing yang melanggar peraturan perundang-undangan negara pantai, dimulai dari perairan pedalaman, perairan kepulauan, laut tertorial atau jalur tambahan, dan juga berlaku terhadap pelanggaran-pelanggaran di ZEE dan landas kontinen dari negara pantai sampai ke laut teritorial negara kapal asing atau negara ketiga.

Kedelapan, kawasan (sea bed area). Kawasan adalah dasar laut dan dasar samudra serta tanah di bawahnya di luar batas-batas yurisdiksi nasional suatu negara. Namun dalam perkembangannya telah diakui prinsip-prinsip warisan bersama umat manusia (common heritage of mankind) serta terbentuknya badan otorita hukum laut ${ }^{27}$.

\footnotetext{
24 Diatur dalam Pasal 56 Konvensi Hukum Laut 1982.

25 Kebebasan Negara tersebut adalah berlayar, memasang kabel dan pipa bawah laut, membangun pulau buatan dan instalasi buatan, menangkap ikan, dan riset ilmiah

26 J awahir Thontowi, op.cit., hlm. 189.

27 Era sebelumnya adalah berlaku prinsip freedom exploitation tanpa kewajiban member i kontribusi, setelah diakui common heritage of mankind terdapat kewajiban kontribusi bagi negara yang mengeksploitasi sebesar $1 \% 7 \%$ kepada masyarakat internasional melalui otorita Hukum laut.
}

\section{Gagasan: Kondisi Riil Pulau-Pulau Terluar di Indonesia}

Pencetusan gagasan ini berasal dari kegelisahan yang timbul saat melihat keadaan pulau-pulau kecil terluar yang sangat memprihatinkan. Salah satu keprihatinan itu karena terbatasnya data dan informasi tentang pulaupulau tersebut, baik itu luas, potensi, karakteristik, dan peluang usaha yang dapat dikembangkan. Keadaan yang juga memprihatinkan adalah sebagian besar pulau-pulau kecil merupakan kawasan tertinggal, tingginya angka kemiskinan yang ditandai dengan persentase angka keluarga pra-sejahtera. ${ }^{28}$ Kondisi yang menyedihkan ini sangat mungkin akibat dari tidak meratanya pembangunan, termasuk kenyataan bahwa penduduk pulau-pulau terluar ini tidak menikmati hasil penjualan sumber daya dari pulau mereka yang dibeli secara illegal oleh pengusaha negara tetangga. ${ }^{29} \mathrm{Hal}$ tersebut didukung dengan perbedaan yang sangat mencolok dalam tingkat kesejahteraan keluarga dengan negara tetangga.

Keterbatasan sarana transportasi serta keterbatasan sarana prasarana telekomunikasi yang menghubungkan antara pulau induk (mainland) dengan pulau-pulau kecil mengakibatkan kurangnya stimulasi terhadap perkembangan dan perlindungan pulau-pulau terluar tersebut. Hal itu diperlukan karena pulau-pulau tersebut terletak pada posisi paling luar negara Indonesia yang rawan akan sengketa batas wilayah maupun rusaknya ekosistem akibat minimnya perhatian pemerintah. ${ }^{30}$

Kondisi kesejahteraan masyarakat setempat juga sangat memprihatinkan. Rasa nasionalisme terhadap negara Indonesia mereka sudah sangat terkikis akibat lebih seringnya mereka

\footnotetext{
${ }^{28}$ Suryo Sakti Hadiwijoyo, 2009, Batas Wilayah Negara Indonesia Dimensi, Permasalahan, dan strategi Penanganan Sebuah Tinjauan Empiris dan Yuridis, Yogyakarta: PT Gava Media, hlm. 113.

29 Bambang Widodo Umar, Manajemen Wilayah Perbatasan, Makalah, disampaikan pada FGD tentang Pengamanan Wilayah Perbatasan di Pontianak, 12 Mei 2008, diakses pada website http://idsps.org/option, com docman / task, cat_view/ gid, 16/ dir, DESC/ order, name/ Itemid, 15/ I imit, $5 /$ limitstart, $0 /$

${ }^{30}$ Departemen Luar Negeri RI, 2010, diakses pada website http:/ / www. deplu. go.id/ Pages/ News. aspx?!DP=38\&I=id pada tanggal 7 Maret 2010.
} 
berinteraksi dengan negara tetangga dibandingkan negara mereka sendiri sebagai akibat lanjutan dari kurangnya sarana transportasi dan telekomunikasi. Di samping itu, rendahnya perhatian pemerintah dan kurangnya perawatan terhadap pulau-pulau kecil terluar itu, baik itu dari sumber daya alam maupun sistem pemantauan patroli dan pengawasan (Monitoring, Controlling, and Surveillance), mengakibatkan semakin renggangnya hubungan mereka dengan Indonesia dan semakin dekatnya hubungan dengan negara tetangga. ${ }^{31}$

Hal yang lebih memprihatinkan lagi adalah terdapatnya kesenjangan perhatian dari pemerintah terhadap pulau-pulau terluar dibandingkan dengan pulau besar. Ini ditunjukkan dengan belum terdapatnya perangkat hukum yang dijadikan landasan pengelolaan pulau terluar, kewenangan pengelolaan masih di tangan pemerintah pusat, lemahnya penegakan hukum, serta belum terdapatnya lembaga pengelola perbatasan. ${ }^{32}$

\section{Kebijakan Pemerintah dalam Mengatasi Per- masalahan di Pulau-Pulau Terluar}

Pemerintah telah berusaha untuk memaksimalkan potensi pulau-pulau terluar tersebut antara lain dengan inventarisasi beserta pemberian nama pulau-pulau tersebut. Hal itu juga didukung oleh kebijakan pemerintah yang dapat dijelaskan sebagai berikut. ${ }^{33}$

Pertama, Peraturan Pemerintah Nomor 47 Tahun 1997 tentang Rencana Tata Ruang Wilayah Nasional tengah di-review dengan memperhatikan aspek-aspek: Penanganan kawasan perbatasan sebagai 'beranda depan' negara dengan memadukan antara pendekatan pertahanan-keamanan dan kesejahteraan masyarakat, Sinergisitas pengembangan wilayah kelautan dengan daratan secara saling menguntungkan melalui pengembangan kawasan andalan laut dan kota-kota pantai, Pengembangan wilayah pesisir dan pulau-pulau kecil dan Penanganan kawasan tertinggal (termasuk pulau-pulau kecil yang terpencil/terisolir) yang

\footnotetext{
${ }^{31}$ Ditj en Kelautan dan Perikanan Bappenas, 2010.

32 Suryo Sakti Hadiwijoyo, op.cit., hlm. 116-118.

33 Diakses pada website : www.litbang.com
}

terintegrasi dalam kesatuan pengembangan kawasan andalan dan pusat-pusat pertumbuhan.

Kedua, Peraturan Presiden Nomor 78 Tahun 2005 tentang Pengelolaan Pulau-Pulau Kecil Terluar yang mempunyai tujuan :

a. Menjaga keutuhan wilayah Negara Kesatuan Republik Indonesia, keamanan nasional, pertahanan negara dan bangsa, serta menciptakan stabilitas kawasan

b. Memanfaatkan sumber daya alam dalam rangka pembangunan berkelanjutan

c. Memberdayakan masyarakat dalam rangka peningkatan kesejahteraan

Ketiga, Pemerintah mengeluarkan peraturan-peraturan terkait Pengelolaan Wilayah Pesisir dan Pulau-Pulau Kecil atau dikenal dengan UU PWP dan PPK. ${ }^{34}$ Undang-undang Nomor. 27/2007 menjadi petunjuk dalam pelaksanaan kebijakan-kebijakan pemerintah terkait wilayah pesisir dan pulau-pulau kecil. Beberapa hal yang diatur dalam UU ini meliputi Perencanaan pengelolaan; Pemanfaatan berdasarkan ekosistem; Pemanfaatan pulau-pulau kecil; Hak Pengusahaan Perairan Pesisir (HP3); Konservasi; Hak akses masyarakat; Pengawasan dan pengendalian; Mitigasi bencana; Sanksi.

Keempat, dibentuknya Badan Nasional Pengelolaan Perbatasan (BNPP). Pembentukan badan itu merupakan amanat Undang-Undang No. 43 Tahun 2008 tentang Wilayah Negara, terutama pada Bab IV Kelembagaan. Sesuai dengan Pasal 14 ayat (1), untuk mengelola batas wilayah negara dan mengelola kawasan perbatasan pada tingkat pusat dan daerah, pemerintah pusat dan pemerintah daerah membentuk Badan Pengelola Nasional dan Badan Pengelola Daerah.

\section{Harapan Melalui Pengelolaan Pulau-Pulau Terluar}

Diharapkan dengan pengelolaan secara integral dan terpadu, maka potensi pulau-pulau terluar dapat dimaksimalkan dan dijabarkan menjadi tiga fungsi utama yaitu fungsi per-

\footnotetext{
${ }^{34}$ Dinas Kelautan dan Perikanan , 2010, diakses pada website http:// www.dkp.go.id/ content. php?c $=4286$ pada tanggal 5 Maret 2010.
} 
tahanan, fungsi ekonomi, dan fungsi konservasi alam.

Pertama, pulau-pulau terluar sebagai fungsi pertahanan bahwa pulau-pulau kecil terluar (terutama di perbatasan) berperan sebagai pintu gerbang ataupun garda depan dalam menjaga keutuhan Negara Kesatuan Republik Indonesia (NKRI). Melalui pengawasan dan perlindungan pulau-pulau terluar maka sekaligus batas-batas wilayah akan terjaga dan terawasi. Dengan demikian ketahanan nasional dan kesatuan wilayah NKRI dapat senantiasa terjaga dan terlindungi dari berbagai ancaman.

Kedua, sebagai fungsi ekonomi yaitu banyak terdapat wilayah bisnis potensial yang berbasis sumber daya (resource-based industry) yang merupakan habitat dan ekosistem penting bagi penyediaan barang dan jasa, termasuk jasa pelayanan pariwisata maupun situs penelitian kelautan yang ternyata memiliki potensi yang begitu luas apabila dikelola dan dikembangkan secara optimal. Hasil-hasil penelitian maupun penyelidikan kelautan memiliki potensi ekonomi yang sangat besar apabila dikemas secara menarik dan ekonomis.

Adapun fungsi ketiga adalah sebagai pengatur iklim global, siklus hidrologi dan biogeokimia, penyerap limbah, sumber plasma nutfah, sumber energi alternatif, dan sistem penunjang kehidupan lainnya yang merupakan penjabaran dari system fungsi ekologis. Fungsi ketiga ini merupakan fungsi yang begitu luas karena menyangkut berbagai sektor dan memiliki manfaat yang luas, tidak hanya bagi masyarakat lokal atau nasional, namun juga dapat dimanfaatkan bagi kepentingan internasional.

\section{Para pihak yang terlibat}

Ide kreatif ini mempertimbangkan peran serta semua warga negara Indonesia termasuk masyarakat yang mendiami pulau-pulau terluar, pemerintah pusat, dan terutama pemerintah daerah untuk dapat membantu mengimplementasikan gagasan ini. Melalui peran serta para pihak dalam implementasi gagasan ini, mereka dapat berkontribusi secara nyata untuk mempertahankan kedaulatan Indonesia melalui per- lindungan atas eksistensi pulau-pulau terluar. Dengan hal ini diharapkan akan terjalin adanya hubungan yang sinergis antara pemerintah pusat, pemerintah daerah (baik provinsi maupun kebupaten/kota) dalam mengelola pulaupulau terluar demi meningkatnya ketahanan nasional, perlindungan wilayah NKRI, dan utamanya demi meningkatnya kesejahteraan masyarakat.

Langkah-langkah strategis yang harus dilakukan dalam pengelolaan pulau terluar yaitu pertama, pemerintah daerah membuat kebijakan yang isinya sesuai dengan keadaan pulau-pulau terluar yang terdapat di daerah yang bersangkutan. Hal tersebut dibutuhkan karena dapat dijadikan sebagai landasan hukum pelaksanaan dan tindakan masyarakat dalam mengelola pulau-pulau terluar. Kebijakan ini hendaknya didasarkan atas realita yang ada di pulau tersebut, sehingga diharapkan kebijakan tersebut sesuai dengan kondisi pulau tersebut, khas dan bersifat spesifik.

Kedua, memberikan pengertian dan pemahaman tentang pentingnya peran pulaupulau terluar bagi ketahanan nasional terhadap masyarakat yang bertempat tinggal di wilayah yang bersangkutan sehingga masyarakat mengerti apa yang seharusnya dilakukan demi kesejahteraan dan keamanan daerahnya. Hal tersebut harus dilakukan dengan cara dan media yang tepat mengingat kondisi masyarakat pulau-pulau terluar yang masih rendah tingkat pendidikannya. Melalui kesadaran yang tumbuh di antara masyarakat pulau-pulau terluar, diharapkan dapat pula dibangun rasa nasionalisme yang lebih baik. Dengan pengertian dan rasa nasionalisme yang cukup, masyarakat akan merasa memiliki pulau yang bersangkutan.

Ketiga, pemerintah pusat lebih memperhatikan kondisi dari pulau-pulau terluar wilayah Negara Kesatuan Republik Indonesia. Hal ini dilakukan dengan cara pembukaan lapangan pekerjaan dan perbaikan pendidikan di pulaupulau terluar. Peningkatan mutu pendidikan dan kesehatan diperlukan karena selama ini pendidikan dan kesehatan pulau-pulau terluar masih memprihatinkan. Perhatian yang diberikan pemerintah pusat hendaknya dapat pula 
memperbaiki jalinan komunikasi yang semula sangat renggang, sehingga stimulasi peningkatan tingkat pendidikan, kesehatan serta kesejahteraan dapat dilakukan secara berkelanj utan.

Keempat, penanaman modal untuk program pembangunan semaksimal mungkin di daerah/wilayah pulau-pulau yang bersangkutan. Hal tersebut dapat dilakukan dengan kerjasama dengan negara tetangga dalam hal ekonomi dan investasi. Hal tersebut dapat dimulai dari tingkat kecamatan dengan pengembangan ekonomi secara selektif dan bertahap dengan memperhatikan tahapan perencanaan sehingga tujuan peningkatan kesejahteraan masyarakat yang akhirnya dapat meningkatkan pendapatan negara, dapat tercapai dengan kerjasama antarnegara. Dengan adanya usaha peningkatan perekonomian ini, diharapkan selain kesejahteraan masyarakat yang ada di pulau-pulau terluar dapat membaik, dapat pula meminimalkan berbagai tindak kejahatan ekonomi (illegal logging, illegal fishing, dan lain-lain) yang terjadi di perbatasan. ${ }^{35}$

Kelima, pemerintah daerah dapat melakukan promosi mengenai potensi pariwisata serta keindahan pulau-pulau kecil terluar yang nantinya dapat meningkatkan pendapatan daerah yang akan mempengaruhi kesejahteraan masyarakat di pulau tersebut. Promosi dapat dilakukan melalui pengiriman duta wisata yang mempromosikan potensi sumber daya, kekayaan pulau yang bersangkutan, serta peluang-peluang investasi baik secara domestik maupun internasional. Melalui promosi ini Indonesia dapat memperkenalkan pulau-pulau tersebut sebagai milik Indonesia, sehingga klaim pulau tersebut sebagai milik bangsa lain dapat dihindari. Di samping itu, usaha ini merupakan usaha pengelolaan secara efektif (effective occupation), sehingga klaim oleh negara lain atas dasar effective occupation

\footnotetext{
${ }^{35}$ Bambang Widodo Umar, Manajemen Wilayah Perbatasan, Makalah, disampaikan pada FGD tentang Pengamanan Wilayah Perbatasan di Pontianak, 12 Mei 2008, diakses pada website http://idsps.org/option, com_docman/ task, cat_view/ gid, 16/ dir, DESC/ order, name/ Itemid, 15/ li mit,5/limitstart,0/ pada bulan November 2010.
}

(seperti halnya Pulau Sipadan dan Ligitan) tidak akan terjadi lagi. ${ }^{36,37}$

Gagasan-gagasan di atas dapat secara sederhana dijelaskan bahwa pengelolaan secara ekonomi mengedepankan peningkatan perekonomian perbatasan melalui kerjasama antar negara sebagai usaha pengembangan pertumbuhan ekonomi; pengelolaan dalam bidang pertahanan keamanan dilakukan dengan cara meningkatkan kesadaran, pengertian masyarakat dan nasionalisme serta dengan melengkapi sarana dan prasarana penunjang bagi masyarakat; dalam bidang sumber daya manusia melalui peningkatan kualitas manusia dan pengembangan kelembagaan masyarakat; serta di bidang sosial budaya melalui pemanfaatan dan perlindungan sumber daya alam secara optimal dengan tetap mempertahankan kearifan lokal.

Apabila langkah-langkah tersebut dilaksanakan, maka diharapkan keberadaan pulaupulau terluar Negara Kesatuan Republik Indonesia yang mempunyai berbagai potensi menjadi lebih diperhatikan secara khusus baik oleh pemerintah pusat, pemerintah daerah maupun masyarakat, sehingga tidak terjadi claim pulau-pulau terluar milik Indonesia oleh negara lain.

Berdasarkan uraian di atas, dapat diringkas beberapa tugas penting bagi bangsa Indonesia dalam melindungi dan melakukan optimalisasi pengelolaan pulau-pulau terluar, antara lain : Pertama, melaksanakan penataan dan penguatan kelembagaan pemerintah pusat maupun daerah sehingga mampu menghasilkan kebijakan yang efektif dan tepat sasaran; Kedua, mewujudkan format kerja terpadu dan komprehensif antara pemerintah pusat dengan pemerintah daerah dengan fokus peningkatan kesejahteraan masyarakat dari aspek sosial, ekonomi, budaya, dan kelembagaan; Ketiga, melakukan pengembangan dan penataan sarana dan prasarana dengan memperhatikan daya dukung lingkungan antara lain transportasi,

\footnotetext{
${ }^{36}$ Brian Taylor Sumner, op. cit., hlm. 1784.

${ }^{37}$ Gillian Triggs, Maritime Boundary Disputes of the South China Sea: International Legal Issues, Legal Studies Research Paper no. 09/37, May 2009, University of Sidney: Sidney Law School.
} 
komunikasi, sumber air bersih, infrastruktur yang mendukung.

Tugas-tugas di atas merupakan tugastugas konseptual yang masih membutuhkan teknik implementasi yang tepat. Berikut ini beberapa teknik implementasi yang ditawarkan oleh penulis, antara lain pertama, memberikan pemahaman terhadap masyarakat beserta pemerintah daerah tentang potensi yang dimiliki oleh pulau-pulau tersebut melalui kunjungan, tatap muka, maupun pemanfaatan media yang menjangkau masyarakat di pulau-pulau terluar; Kedua, melakukan inventarisasi, kajian pengeIolaan, dan pengembangan potensi pulau-pulau terluar; Ketiga, melakukan diskusi panel, seminar, atau lokakarya yang melibatkan pemerintah pusat, pemerintah daerah, masyarakat, dan tim ahli mengenai potensi dan formula pengelolaan yang harus dilakukan, baik secara umum maupun secara spesifik bagi tiap-tiap pulau atau kumpulan pulau dengan karakteristik tertentu yang serupa; Keempat, mewujudkan iklim dan peluang usaha yang kondusif bagi investasi dengan mengembangkan pola kemitraan dan kerja sama antarnegara, Kelima, meningkatkan kualitas sumber daya manusia melalui pelatihan keterampilan bagi masyarakat, pengembangan pendidikan, kesehatan, perhubungan, komunikasi dan informasi.

Berdasarkan gagasan yang telah penulis utarakan terdapat beberapa hal yang dapat kita peroleh sebagai hasil dari implementasi strategi di atas, antara lain pertama, dilaksanakannya kerjasama dengan negara tetangga, maka akan meningkatkan kualitas kerjasama dengan negara tetangga, khususnya dalam bidang perdagangan; Kedua, terwujudnya sekitar 200 pulau kecil yang memiliki infrastuktur yang memadai; Ketiga, terciptanya ekosistem yang seimbang dengan dilakukannya pengelolaan sumber daya alam hayati; Keempat, meningkatknya iklim investasi dan perdagangan yang dapat meningkatkan kesejahteraan ekonomi masyarakat; Kelima, terciptanya koordinasi dan sinkronisasi antara pemerintah pusat, pemerintah daerah, dan masyarakat dalam hal pengembangan dan pendayagunaan teknologi pendukung pembangunan pulau-pulau terluar; dan
Keenam, terwujudnya kedaulatan negara yang utuh, sebagai hasil dari pengelolaan yang efektif oleh masyarakat lokal terhadap pulaupulau terluar.

\section{Penutup}

Negara Kesatuan Republik Indonesia merupakan negara kepulauan yang dengan jumlah pulau terbesar di dunia dan memiliki kekayaan yang berlimpah, tak terkecuali yang terkandung dalam pulau-pulau terluarnya. Pulau-pulau terluar merupakan sumber kekayaan yang belum tergarap sekaligus garda depan ketahanan dan keamanan negara. Tanpa pengelolaan dan perlindungan yang optimal, kekayaan negara sangat mudah dicuri oleh pihak luar dan keamanan negara pun terancam. Sehingga usaha-usaha perlindungan dan pengelolaan harus segera dilakukan.

Penguatan kelembagaan pemerintah yang diikuti dengan kerja sama antara pusat dan daerah, diharapkan mampu memberikan perhatian dan pengelolaan yang lebih baik terhadap pulau-pulau terluar. Ditunjang dengan peningkatan sumber daya manusia dan peningkatan kesejahteraan masyarakat dengan memanfaatkan potensi pulau-pulau terluar, maka kerja sama antara pemerintah dan masyarakat dapat senantiasa menjaga keutuhan bangsa melalui pulau-pulau terluar di wilayah Negara Kesatuan Republik Indonesia.

\section{DAFTAR PUSTAKA}

Anonim. Permasalahan Kelautan Yang Muncul Dalam Negara Kepulauan Indonesia. diakses pada website http:// www. sumba wanews. com/ berita/ opini/ permasalahan -kelautan-yang-muncul-dalam-negarake pulauan-indonesia/pdf.html tanggal 5 Maret 2010;

Departemen Luar Negeri RI, diakses pada website http:// www.deplu.go.id/ Pages/ News. aspx?IDP=38\&|=id pada tanggal 7 Maret 2010;

Dinas Kelautan dan Perikanan. 2010. diakses pada website http://www.dkp.go.id/ content. php?c $=4286$ tanggal 5 Maret 2010; 
Hadiwijoyo, Suryo Sakti. 2009. Batas Wilayah Negara Indonesia Dimensi, Permasalahan, dan strategi Penanganan Sebuah Tinjauan Empiris dan Yuridis, Yogyakarta: PT Gava Media;

Kantor Berita Antara, diakses pada website http:/ / www. antara.co.id/ view/ ?i=12284 $82066 \& c=N A S \& s=$ pada tanggal 5 Februari 2010;

Ma'arif, Syamsul. 2009. Makalah Pengelolaan Pulau Terluar dalam Manajemen Pulau Terluar. Fakultas Geografi UGM. 23 J anuari 2009;

Parthiana, I Wayan. 2003. Pengantar Hukum Internasional. Bandung: Mandar Maju;

Shaw, Malcolm N. 1997. International Law. Cambridge: Cambridge University Press;

Susanto, Bambang. "Kajian Yuridis PermasaIahan Batas Maritim Wilayah Laut Republik Indonesia (Suatu Pandangan TNI AL Bagi Pengamanan Batas wilayah Laut RI)". Indonesian J ournal of International Law, Special Edition December 2004;

Sumner, Brian Taylor. "Territorial Disputes at The International Court of J ustice", Duke Law J ournal vol. 53. 2004;

Thontowi, Jawahir. 2006. Hukum Internasional Kontemporer. Bandung: Refika Aditama;

Triggs, Gillian. "Maritime Boundary Disputes of the South China Sea: International Legal Issues". Legal Studies Research Paper No. 09/ 37, May 2009

Umar, Bambang Widodo. Manajemen Wilayah Perbatasan. Makalah. disampaikan pada FGD tentang Pengamanan Wilayah Perbatasan di Pontianak. 12 Mei 2008. diakses pada website http://idsps.org/ option, com docman/task, cat view/ gid, 1 6/ dir, DESC/ order, name/ Itemid, 15/ limit, $5 /$ limitstart, $0 /$. 